\title{
Rice Production under the Youth Empowerment Scheme in Nasarawa State, Nigeria
}

Yahaya, H., Luka, E. G., Onuk, E.G., Salau, E.S. and Idoko, F.A. e-mail: hyjoe@gmail.com; mobile: 07037867120

Department of Agricultural Economics and Extension, Nasarawa State University, Keffi.

\begin{abstract}
The study was conducted to analyze rice production under the Youth Empowerment Scheme (YES) in Nasarawa State, Nigeria. A multi-stage sampling technique was used to select 160 rice farmers made up of 80 participants of YES and 80 non participants. Primary data were collected through the use of structured questionnaires and personal interview. Data were subjected to descriptive statistics, linear regression and t-test. Majority of the respondents were less than 31 years and 31 to 40 years for participants and non participants, respectively. The respondents were mostly males and married with a minimum of secondary school education. Majority (62.5\%) and (70\%) of the participants and non participants, respectively were engaged in farming as main occupation, with less than 7 years farming experience and cultivating less than three hectares of land. Annual income and farm size had positive and significant effect on rice production with an $R^{2}$ value of 0.895 . There was no significant difference $(t=0.265 ; p>0.05)$ between the yield of participants and non participants. Inadequate funds, high cost of agrochemicals, and inadequate extension services were the serious constraints to rice production. The study therefore, recommends that more efforts need to be put in place by government and all relevant stakeholders to provide adequate funds, agrochemicals and extension services.
\end{abstract}

Keywords: Rice Production, Youth Empowerment Scheme, Agricultural Transformation

\section{Introduction}

Nigeria is the most populous country in Africa with a population of over 130 million people, with its domestic economy dominated by agriculture, which accounts for about $40 \%$ of the Gross Domestic Product (GDP) and two-thirds of the labour force (Akande, 2002). The major food crops include cereal crops such as sorghum, maize, millet, rice, wheat etc. According to Akande (2002) rice is one of the most important crops and supplies a quarter of the entire caloric intake of the human race. He further argued that it is a staple food for more people than any other crop and $90 \%$ is grown and consumed in South East Asia, which is a major centre of the world population. Rice is an increasingly important crop in Nigeria, it is grown both for sale and home consumption.

The Federal Ministry of Agriculture in Amaza and Olayemi, (2002) estimate that the annual supply of food crops (including rice) would have to increase at an average annual rate of $5.9 \%$ to meet food demand and reduce food importation significantly. Studies have shown that aggregate rice production in Nigeria has been growing at about 2.5\% per annum in recent years (Olayemi, 1998; Akinbili, 2002; Amaza and Olayemi, 2002). But the annual rate of population growth has been high (about 3\%) (Akinbola, 2002). The reality is that Nigeria has not been able to attain self-sufficiency in rice production despite increasing hectares put into production annually (CBN, 2000). 
The National Poverty Eradication Programme (NAPEP) was established in 2001 to address the challenges of poverty in the country. As one of its important area of interest NAPEP has designed the Youth Empowerment Scheme (YES) in other to achieve its objectives among others. It is a sustainable development initiative of the programme specifically targeted at youths to make them economically and socially responsible and self-reliant, via agriculture, business and skill acquisitions through technical and managerial training. YES is also aimed at addressing the problem of unemployment among the youths of Nigeria (NAPEP, 2001). With good training and greater opportunities they could contribute significantly to rice production.

Recently the Nigerian government is making some strides in the reduction of the dependence of imported rice as well as to develop the local rice industry, this has done through the launching of the presidential initiative on accelerated rice production. Government also plans to ban rice imports through the rice transformation agenda as from 2015, at which time the nation would have achieved self sufficiency in rice production in line with the rice implementation action plan (Transforming the Nigerian Agricultural Landscape, 2012). Platforms such as the YES initiative can be used as a launching ground to achieve the transformation agenda.

Nasarawa state is one of the major rice producing areas in Nigeria where production capacity was estimated at 655,000 metric tons/ha from 2003-2008 (NADP, 2010). This provides employment opportunities for the people in the area, especially the youths.

This study was carried out principally to analyze small scale rice production under the Youth Empowerment Scheme in Nasarawa State. Specifically the study set out to; determine the effect of socioeconomic characteristics of participants on the yield of rice; and identify factors militating against rice production among the respondents in the study area. The study also postulated a hypothesis.

\section{Methodology}

Nasarawa state is both an agrarian and commercial entity. It lies between latitudes $08^{\circ} 32^{\prime}$ and $8^{\circ} 18^{\prime}$ and longitudes $06^{\circ} 15^{\prime}$ and $08^{\circ} 50^{\prime}$. It occupies an area of about 27,117 square kilometers (Wikipedia, 2012). Nasarawa state is bounded in the north by Kaduna state, in the west by the Federal Capital territory, in the south by Kogi and Benue states and in the east by Taraba and Plateau states. The population of Nasarawa state is multi-ethnic and based on the 2006 census is about 1.86 million (NPC, 2006).

Nasarawa state is made of three agricultural zones: the southern, western and central zones. The research was conducted in the southern agricultural zone of Nasarawa state consisting of Awe, Doma, Keana, Obi and Lafia. This zone was chosen because most of the rice produced in the state comes from that area. The population for this study consisted of both the participants and non-participants of YES. A multistage random sampling technique was used. In the first stage four local governments were purposively selected from the zone, this was to ensure that all the local government areas identified were covered by YES programme. Two districts were randomly selected from each of the four local governments making eight districts, and this was followed by a random selection of two communities from each of the district to give a total of sixteen communities. Ten respondents were selected from each of these communities making sure that five were participants and five were non-participants of YES. A total of 160 respondents with 80 participants and 80 non-participants of YES programme were sampled for the study. 
Primary data were used for this study and collected through the use of structured questionnaires and personal interview. Descriptive (frequency, mean, percentage and ranking) and inferential statistics (linear regression and t-test) were used to analyze the data.

The regression model used is specified as follows:

$\mathrm{Y}=b_{o}+b_{1} x_{1}+b_{2} x_{2}+b_{3} x_{3}+b_{4} x_{4}+b_{5} x_{5}+b_{6} x_{6}+u$

Where

$\mathrm{Y}=$ yield of rice of $\mathrm{YES}$ participants. $(\mathrm{Kg} / \mathrm{ha})$

$\mathrm{X}=$ socioeconomic characteristics of YES participants

$\mathrm{b}_{0}=$ constant

$b_{1}-b_{7}=$ coefficients of the independent variables

$x_{1}=$ age of the respondents (years)

$x_{2}=$ educational level (years)

$x_{3}=$ income (naira)

$x_{4}=\operatorname{sex}$ (male or female)

$x_{5}=$ farming experience (years)

$x_{6}=$ farm size $(\mathrm{ha})$

A t-test was used to establish the difference between the rice yield of the participants and non-participants.

\section{Results and Discussion}

\section{Socio-economic characteristics of respondents}

Results from table 1 showed that majority (42.5\%) of the YES participants were less than 31 years, while for the non participants, about (27.5\%) were within the ages $31-40$ years. This is an indication that the majority of both YES participants and non participants were within the active productive age, and if properly empowered can enhance agricultural production. Similarly table 1 shows majority $(90 \%)$ of the YES participants were males while female respondents constituted $10 \%$. Whereas, $87.5 \%$ of the non participants' respondents were males while female respondents constituted $12.5 \%$ of the non participants. This implies that male farmers dominated rice production that for both participants and non participants in the study area. This agrees with Onuk (2008) that males constitute the majority in rice production because females are mainly involved in domestic works. The marital status as shown in table 1 indicates that majority $(62.5 \%)$ of the participants and $(82.5 \%)$ were married. This implies that majority of the respondents can make use of family labour to increase production. The study also revealed that majority (55\%) of the YES participants have secondary school education, the same majority goes for the non participants where $35 \%$ attended secondary school. Education is the bed rock of development and is also known to facilitate farmers understanding and the use of improved crop production practices. Thus, both sets of participants could take the advantage of their education for better production. With regards to occupation, majority $(62.5 \%)$ of the YES participants were engaged in farming as their main occupation. The same situation also applies for the non participants, where majority 
$(70 \%)$ were also engaged in farming, having farming experiences of less than 7 years for majority $(65 \%)$ of the YES participants and $47.5 \%$ for the non participants implying that majority of the respondents were not very experienced in the farming business. Both sets of respondents had less than 3 hectares of land meant for rice production in the study area, with $87.5 \%$ for the participants while it was $80 \%$ of the non participants. This showed that the respondents are mostly small scale farmers.

Table 1: Socio-economic characteristics of respondents

\begin{tabular}{|c|c|c|}
\hline Characteristics & $\begin{array}{l}\text { YES participants } \\
\text { Percentage }\end{array}$ & $\begin{array}{l}\text { Non participants } \\
\text { Percentage }\end{array}$ \\
\hline \multicolumn{3}{|l|}{ Age (years) } \\
\hline$<31$ & 42.5 & 20.0 \\
\hline $31-40$ & 37.5 & 27.5 \\
\hline $41-50$ & 20.0 & 22.5 \\
\hline $51-60$ & 0 & 20.0 \\
\hline$>60$ & 0 & 10.0 \\
\hline Total & 100.0 & 100.0 \\
\hline \multicolumn{3}{|l|}{ Sex } \\
\hline Male & 90.0 & 87.5 \\
\hline Female & 10.0 & 12.5 \\
\hline Total & 100.0 & 100.0 \\
\hline \multicolumn{3}{|l|}{ Marital status } \\
\hline Single & 37.5 & 17.5 \\
\hline Married & 62.5 & 82.5 \\
\hline Total & 100.0 & 100.0 \\
\hline \multicolumn{3}{|l|}{ Occupation } \\
\hline Farming & 62.5 & 70.0 \\
\hline Trading & 5.0 & 2.5 \\
\hline Artisan & 2.5 & 7.5 \\
\hline Civil servant & 25.0 & 20.0 \\
\hline Others & 5.0 & 0 \\
\hline Total & 100.0 & 100.0 \\
\hline \multicolumn{3}{|c|}{ Farming experience } \\
\hline$<7$ years & 65.0 & 47.5 \\
\hline $8-15$ & 27.5 & 35.0 \\
\hline $16-23$ & 7.5 & 12.5 \\
\hline$>24$ & 0 & 5.0 \\
\hline Total & 100.0 & 100.0 \\
\hline \multicolumn{3}{|l|}{ Farm size } \\
\hline$<3 \mathrm{ha}$ & 87.5 & 80.0 \\
\hline 3ha and above & 12.5 & 20.0 \\
\hline Total & 100.0 & 100.0 \\
\hline
\end{tabular}

Source: Field survey, 2010 


\section{Effect of Socio-Economic characteristics on rice yield of Participants}

The results in table 2 shows that four of the independent variables-sex, level of education, farming experience and age of the participants had no significant effect on rice production. However, income was significant at $5 \%$ level while farm size was highly significant at $1 \%$ level. This implies that rice production of YES participants was dependent on income from the sale of rice and on the farm size of the participants. Marginal reduction in these variables will lead to correspondent reduction in the yield of rice. The $R^{2}$ value of 0.895 implies that $89.5 \%$ of the variation in the dependent variable (Yield) was explained by the independent variables included in the regression model.

Table 2: Regression of socio-economic characteristics on rice yield of participants

\begin{tabular}{lllll}
\hline Variable & $\begin{array}{l}\text { Regression } \\
\text { coefficients }\end{array}$ & $\begin{array}{l}\text { Standard } \\
\text { error }\end{array}$ & t-value & Significance \\
& 48.861 & 27.427 & $1.781^{*}$ & .085 \\
\hline Constant $(\mathrm{a})$ & -.149 & .697 & $-.214^{\mathrm{NS}}$ & .832 \\
Age (yrs) & -.947 & 1.174 & $-.807^{\mathrm{NS}}$ & .426 \\
Level of education (yrs) & $7.475 \mathrm{E}-5$ & .000 & $2.592^{* *}$ & .015 \\
Income (N) & 3.073 & 11.335 & $.271^{\mathrm{NS}}$ & .788 \\
Sex & -.311 & .850 & $-.366^{\mathrm{NS}}$ & .717 \\
Farming experience (yrs) & 41.864 & 7.385 & $5.669^{* * *}$ & .000 \\
Farm size (ha) & & & & \\
\hline
\end{tabular}

$\mathrm{R}^{2}=0.895 ; \mathrm{F}-$ value $=36.576^{* * *} .{ }^{* *} \mathrm{p}<0.05,{ }^{* * *} \mathrm{p}<0.01$

Source: Field Data, 2010

Factors affecting rice production among participants.

The results in table 3 revealed that the most serious constraints to rice production in the study area are inadequate funds, high cost of agrochemicals, shortage of labour, inadequate extension service, and weed and diseases. Others are cost and unavailability of improved seeds.

These constraints limit the quantity or capacity of rice production in the study area. The implication is that as long as these constraints or hurdles remain, production capacity may not grow beyond subsistence level thereby, resulting to food insecurity since rice serves as a staple food for many Nigerians. This is however, surprising as the YES programme is supposed to take care of most of these constraints. 
Table 3: Distribution of factors militating against rice production among participants.

\begin{tabular}{lll}
\hline Variables & Percentage (\%) & Rank \\
\hline Inadequate funds & 100.0 & 1 \\
High cost of agrochemicals & 95.0 & 2 \\
Shortage of labor & 90.0 & 3 \\
Inadequate extension service & 90.0 & 3 \\
Weed and disease & 70.0 & 4 \\
Cost of seeds & 67.5 & 5 \\
Unavailability of improved seeds & 57.5 & 6 \\
Others (flood and birds control) & 20.0 & 7 \\
\hline
\end{tabular}

Source: Field survey, 2010

*Multiple responses

\section{The difference in yield of rice between participants and non-participants of YES}

The results in table 4 showed that the mean yield per hectare of participants is 1755 $\mathrm{kg}$ per hectare, whereas the non participants had a mean yield of $1299 \mathrm{~kg}$. The results showed that there was no significant difference in the yields of participants and nonparticipants, meaning that there was no positive impact of the scheme on participants in terms of yield. Thus, the null hypothesis is accepted that there is no significant difference between the yields of participants and non participants. The YES programme in the study area has not been able to achieve its cardinal objective of increasing rice production among the participants, rather it has treaded the path of most of such government programmes. This buttressed the view of Ihimodu (2004) who stated that empirical records of government intervention programmes and projects are not impressive enough to bring about the expected transformation of the livelihood of the targeted population.

Table 4: T-test showing the difference in yield of rice between participants and non participants

\begin{tabular}{llllll}
\hline Variable & Mean & SD & Mean Diff. & T & Sig. \\
\hline YES & 1755.7500 & 11344.36033 & 1596.25000 & .871 & $.265^{\text {NS }}$ \\
participants & & & & & \\
$\begin{array}{l}\text { Non- } \\
\text { participants }\end{array}$ & 1299.5000 & 2345.31584 & & & \\
\hline
\end{tabular}

Source: Data analysis, 2010. Dependent variable: yield

\section{Conclusion}

The YES programme has not been able to contribute adequately to empowering the youths of Nasarawa state to bring about the needed transformation in rice production. Given the endemic poverty situation in the country, more efforts need to be put in place to arrest the situation and make life meaningful for the citizenry. There are quite a number of programmes introduced by the government, however, these poverty measures failed to achieve the desired results largely due to political interference, absence of effective monitoring and coordination mechanism and lack of continuity mainly due to frequent change of governments. 


\section{Recommendation}

1. More efforts need to be put in place to make the YES programme practicable and sustainable not just on paper but in reality, this will go a long way in alleviating the issue of food insufficiency especially in rice production, since a lot of people take rice to be a staple food.

2. NAPEP should increase the amount of loan for rice farmers through commercial banks and other lending institutions, making it more accessible to farmers without bureaucracy.

3. Due to the economic value of rice, there should be adequate extension services to educate and disseminate new technologies which are pivotal if food security and sufficiency must be sustained.

\section{References}

Akande T. (2002). An overview of the Nigerian Rice Economy: Integrated Assessment of the WTO Agreement on Rice sector, Geneva, Switzerland, pp 1-3.

Akinbile, L.A. (2002). Technology dissemination, agricultural productivity and poverty reduction and the Nigerian agricultural sector. El-Shaddai Global Ventures Ltd. Ibadan, pp 27-35.

Akinbola, G.E. (2002). Poverty reduction through the crop subsector in Nigeria: A regional Perpective. El-shaddai Global Ventures Ltd, pp39-52.

Amaza, P.S. and Olayemi J.K (2002). Analysis of technical inefficiency in food crop production in Gombe State. Nigerian Journal of Applied Economics Letters. 9 (2): 51-54.

Central Bank of Nigeria (2000). Statistical Bulletin Vol. 2 No.2.

Ihimodu, I.I. (2004). Marketing of Agricultural Products and the Food Security programme in Nigeria. Paper Presented at the 13th Annual Congress of the Nigeria Rural Sociological Association at LAUTECH, Ogbomosho, Nigeria, 25-28.

Lafia Local Government Information Unit (2010). A Bulletin of Nasarawa State.

Nasarawa State Agricultural Development Project (NADP). 2010. A bulletin.

National Poverty Alleviation Programme (NAPEP). (2002). Federal Republic of Nigeria. The Presidency, Abuja.

National Planning Commission (NPC) (2006). Abuja.

Olayemi, J.K. (1998). Food Security in Nigeria. Research Report No.2, Development Policy Centre, Ibadan Nigeria, pp.1-85

Onuk, G.E. (2008). Meeting the challenges of rice demands through Children and Youths - in - Agriculture. A paper presented at the $10^{\text {th }}$ Annual Conference of the National Research and Development, Network of Children and Youth-in-Agriculture programme (CYIAP), November.

Ovwigbo B.O and Ifie, P.A (2004): Principles of Youth Development. A Reference Manual for Development Countries. 